\title{
A 15-17. századi távolsági textilkereskedelem régészeti emlékei Pápán
}

\author{
MORDOVIN MAXIM \\ ELTE BTK Régészettudományi Intézet, Magyar Középkori és Kora Újkori Régészeti Tanszék \\ H-1088 Budapest, Múzeum krt. 4/B, mordovin.maxim@btk.elte.hu
}

\begin{abstract}
Mordovin, M.: The archaeological traces of the 15th-17th centuries distance cloth-trade in Pápa
Abstract: The rescue excavations carried out in the centre of Pápa produced a huge number of very different finds. Among others more than one hundred cloth seals were found, which number is higher than the all other such from the territory of the whole medieval Kingdom of Hungary. These seals represent a very intensive distance trade of cloth production in 15th-17th centuries between Pápa and several important western centres of cloth-production, including Cologne, Ulm, Nuremberg, Arras, Hamburg etc. The finds from Pápa supplement the data known from the written sources concerning the cloth trade.
\end{abstract}

Keywords: cloth seals, textile production, urban archaeology, international trade

\section{Bevezetés}

A nyugat-dunántúli Pápa városában 2010-ben kezdődtek meg a belváros nagyszabású rehabilitációs munkálatai, melyek egyik legfontosabb része a Fő tér felújítása volt. Az építkezések előtt itt még lehetőség nyílt jelentősebb megelőző feltárásokra. A munkák első szakaszát Szvath Márton, míg a 2011. évit Mordovin Maxim és Kolláth Ágnes vezették. ${ }^{1}$

A több mint $1700 \mathrm{~m}^{2}$-es felületet érintő feltárás rendkívül gazdag leletanyagot és a város középkori történetére vonatkozóan óriási mennyiségű topográfiai adatot szolgáltatott. Jól nyomon lehetett követni, hogy a kora Árpád-kori falusias település hogyan alakult át a 13. század végére egy burkolt piactérrel rendelkező mezővárossá, amely a középkor végére a távolsági kereskedelem egyik kiemelkedő csomópontjává vált. ${ }^{2}$

A középkor végére alakult ki Pápa központjának az a szerkezete - gótikus templommal, körülötte kőkerítéssel körülzárt temetővel és burkolt piactérrel -, amely a 18. század második feléig meghatározó maradt.

Pápa város történetében a 15-16. század fordulója volt egyértelműen a virágkor kezdete. A város ekkor az országosan meghatározó befolyású Szapolyai család dunántúli birtokainak központja lett. ${ }^{3}$ Elősegítette a gazdaság további fellendülést a mohácsi csata utáni népességmozgás is. A pápai és a környékbeli lakosság (és azon belül is elsősorban a nemesség) egyre inkább a város erődítésein belül keresett menedéket.

Az 1540-es évektől Pápa annak a győri végvidéknek lett egyik vára, amely a 16. század második felében a végvárrendszer egyik legzavartalanabbul müködő egységének tekinthető, elsősorban annak köszönhetően, hogy a katonaság zsoldjának 60\%-át - éppen Bécs és Ausztria védelme érdekében - a határos osztrák tartomány, Alsó-Ausztria segélyeiből fizették (ez még abban is megmutatkozott, hogy a források több alkalommal a területet „osztrák végeknek" nevezték). ${ }^{4}$

A nagyszámú környékbeli nemes beköltözése a 16. század közepére elég gyorsan helyszűkéhez vezetett, így a piactér északi és nyugati részét beépítették. Két házsor épült ekkor a templom körítőfala mentén (1. kép).

Erre az időszakra tehető a textilkereskedelem fellendülése is, ami egybevág az írott forrásokkal. A városi posztókereskedőkről 1477-től kezdve tudunk ${ }^{5}$, míg az első ismert pápai céh - a szabóké - 1510-ben alakult meg. ${ }^{6}$ Helyi textilgyártásra utalnak a 15. században említett posztókallómalmok is. A textilkereskedelmet is jelentősen elősegítette a Garai László által 1439-ben a város részére megszerzett harmincadmentesség, vagyis a határvámok fizetése alóli felmentés. Ezt a kiváltságot 1500-ban és 1518-ban teljes vámmentességre egészítették ki.7 A 16. század folyamán már nagyszámú pápai textilkereskedőről tudunk Északnyugat-Magyarország vásárain, sőt, Béccsel folytatott kereskedelemben is. 1494-ben egy pápai csapó nevével találkozunk a bécsi

1 Részletesen lásd Mordovin 2012

2 Az Árpád-kori település leletanyagát Herbst Anna dolgozza fel. (Herbst Anna: Egy Árpád-kori településrészlet feltárása a pápai Fő téren. ELTE BTK BA szakdolgozat, Budapest 2013.)

3 Kubinyi 1994. 54.

4 Pálffy 1997. 9., Pálffy 1999. 60., 70., 116., 128-129., 169-172.

5 Solymosi 1996. 23.

6 Kubinyi 1994. 54-55., S. Lackovits 1996. 80.

7 Kubinyi 1994. 54.

ISSN 2064-1966 (Print); ISSN 2631-0376 (Online) 
egyetemen. ${ }^{8}$ A 16-17. században a pápai kereskedők nagy mennyiségú kézmúiparhoz szükséges „alapanyagot" hoztak Bécsből, ennek $62 \%$-a posztó volt. ${ }^{9} \mathrm{~A}$ végvárrá alakuló településen a textilkereskedelem még kiemeltebb szerephez jutott. A korszakban közismert a végvári katonák posztóval való fizetése. Ez a posztó azonban nem annyira ruházkodásra szolgált, hanem pénzhelyettesítő funkciója is volt, így a katonaság ezt a helyi piacon - ahogyan más végvárakban is - továbbadta. ${ }^{10}$ Mivel a pápai katonaságot nagyrészt az osztrák és a birodalmi rendek segélyeiből fizették ${ }^{11}$, így a páratlan mennyiségü nyugati (német és osztrák) eredetű textilplomba jelenléte könnyebben magyarázhatóvá válik. Ezek közül a nürnbergi és a bécsi plombák tökéletesen megerősítik az írott források adatait (3. kép 7., 5. kép 7.). ${ }^{12}$ Többek között erre az intenzív kereskedelemre települt rá a helyi szabócéh, amely ezt a posztót felvásárolta, feldolgozta és értékesítette. ${ }^{13}$

\section{A textilplombák megjelenése és használata Nyugat-Európában}

A textilplombák, más néven posztóbárcák ${ }^{14}$, posztópecsétek vagy ólombélyegek ${ }^{15}$ a nyugat-európai textilgyártás minőség- és eredetiségjelzői. Ezek a posztókészítés folyamatának legkülönbözőbb lépcsőfokaihoz kapcsolódtak, de minden esetben azt jelezték, hogy az aktuális szakaszban a plombával ellátott darab megfelelt az adott város által támasztott minőségi és mennyiségi előírásoknak. Az írott szabályozás a 14. század második felében érte el a csúcspontját, olyan aprólékossá válva, hogy már szinte teljesen gátat vetett az önálló kezdeményezésnek. ${ }^{16}$

A plombák használatát is nagyon szigorú szabályok határozták meg. A nyugati nyelvekben általában posztópecsétnek (cloth seal; tuchsiegel), ritkábban posztóplombának (tuchplombe), vagy posztóólomnak (lakenlood) nevezett ólomplombákat csak meghatározott, az adott város tanácsa által megbízott (kinevezett) tisztségviselők adhatták, miután leellenőrizték, hogy a lepecsételendő posztóvég megfelel-e a minőségi és mennyiségi elöírásoknak. A tisztségviselők elnevezése angolul alnager, holland és német nyelvben wardein vagy warden volt. Az utóbbi az „őr" vagy „ellenőr" jelentésű francia gardien szóból származik. A pecsételési joggal rendelkező minőségellenőr feladatköre az volt, hogy a posztókészítés minden fázisában ellenőrizze a készülő terméket. ${ }^{17}$ Természetesen a késő középkor folyamán ez a tevékenység maga is tovább differenciálódott, egész hivatal jött létre, mintakönyvekkel és számos, a posztókészítési folyamat egyes lépéseit - így például a festést is - különkülön ellenőrző tisztségviselőkkel. A posztó megjelölését nagyon komolyan vették. A szigorúságot jól jelzi egy szemléletes példa 1371-ből, egy kis holland textilgyártó városkából, 's Hertogenboschból. Miután kiderült, hogy két pecsételő mester olyan szövetre tett pecsétet, amely nem felelt meg a városi minőségi elő́rásoknak, vagyis nem kaphatta meg a minőségjelző pecsétet, a tevékenységet a város elleni bűncselekménynek nyilvánították. A két férfi súlyos büntetést kapott: soha többet nem foglalkozhattak kereskedelemmel, s nem viselhettek városi hivatalokat sem, sőt, az egyiküket elúzték a városból. ${ }^{18}$

A posztópecsételés gyakorlatának kezdetei és eredete bizonytalan. Az ellenőrzés és minőségbiztosítás igénye már elég korán megjelenhetett. Kölnben például már 1230-ban rendelkeztek a posztóáru „hitelesítéséről". ${ }^{19}$ A nyugati kutatások feltételezik, hogy az első plombák még viaszból készülhettek, és csak a szabályozás egyre bonyolultabbá válásával jelent meg, és terjedt el széles körben a posztó ólombulla-szerű pecsétekkel való megjelölése. Erre jó adatokat szolgálnak az angliai írott források, melyek szerint a posztóminőség-jelző ólom- és a viaszpecséteket még a 15. században is párhuzamosan használták. A viasz használatát ezen a területen csak a 16. században, újabb szabályozás révén zárták ki. ${ }^{20} \mathrm{Az}$ eddigi legkorábbi ólomból készült textilplombák mind Hollandiából származnak. Az egyik legrégebbi, 1275-re keltezhető darab Leiden városához kapcsolható. ${ }^{21}$ Ennek ellenére még a 14. századi plombák is nagyon ritkák. Annál több azonban a használatukra vonatkozó adat. Így például Brugge-ben 1282-ben azt szabályozták, hogy a gyapjú származási helyétől függően milyen jelzés kerüljön az ólombélyegre. ${ }^{22} \mathrm{~A}$ 14. század elején Ypernben már hatalmas

8 Kubinyi 1994. 57

9 Szakály 1994. 97

10 Gecsényi 1996. 44-45.

11 Pálffy 1997. 9.

12 Szakály 1994. 97.

13 Gecsényi 1996. 45.

14 Tettamanti 1994. 111

15 Endrei 1989. 57. Nem szeretnék kizárólagosan állást foglalni egyik elnevezés mellett sem, hanem inkább szinonimaként használom őket a továbbiakban.

16 Rodenburg 2007. 26.

17 Rodenburg 2007. 28.

18 Hofenk de Graaf alapján: Rodenburg 2007. 27.

19 Kaiser 1988. 731.

20 Lásd Egan 1985.

21 Rodenburg 2007. 31

22 Munro 2005. 432. 


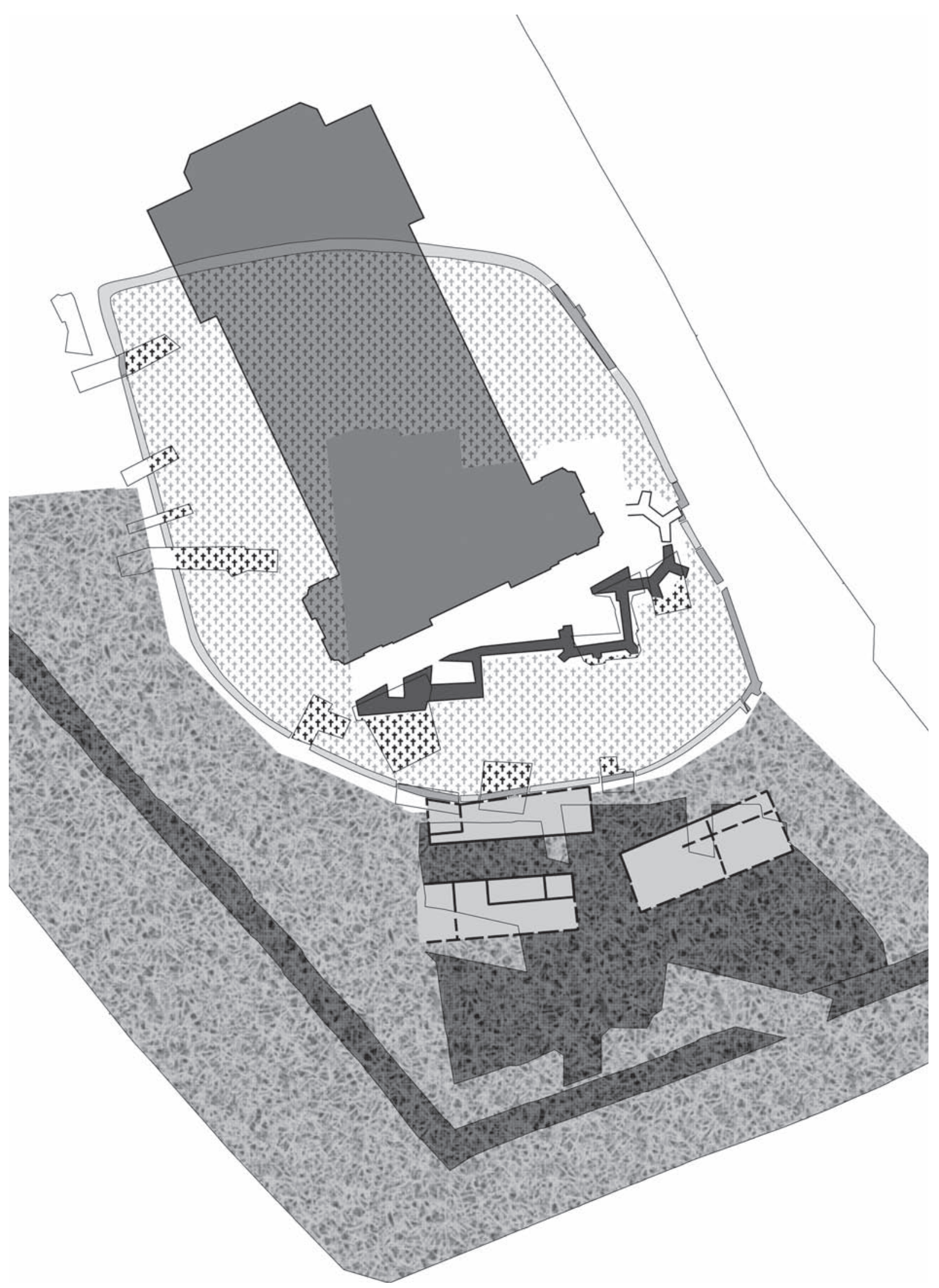

1. kép: A pápai piactér rekonstruált kiterjedése a 15-16. században a 2010-2011. évi feltárások alapján 


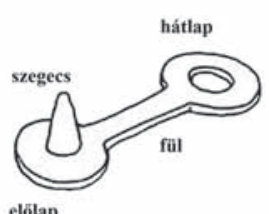

ê̄̆lap

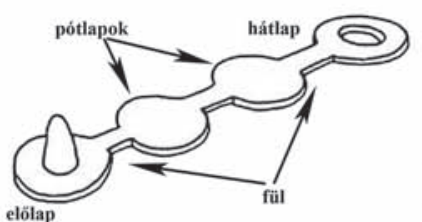

1.

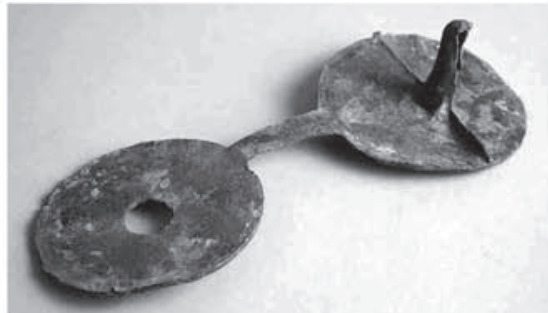

2.
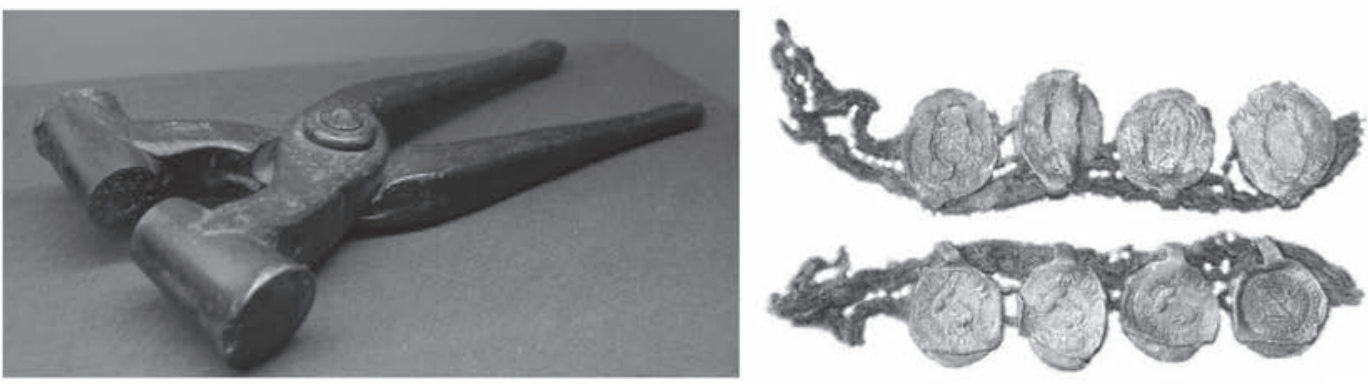

3.

4.
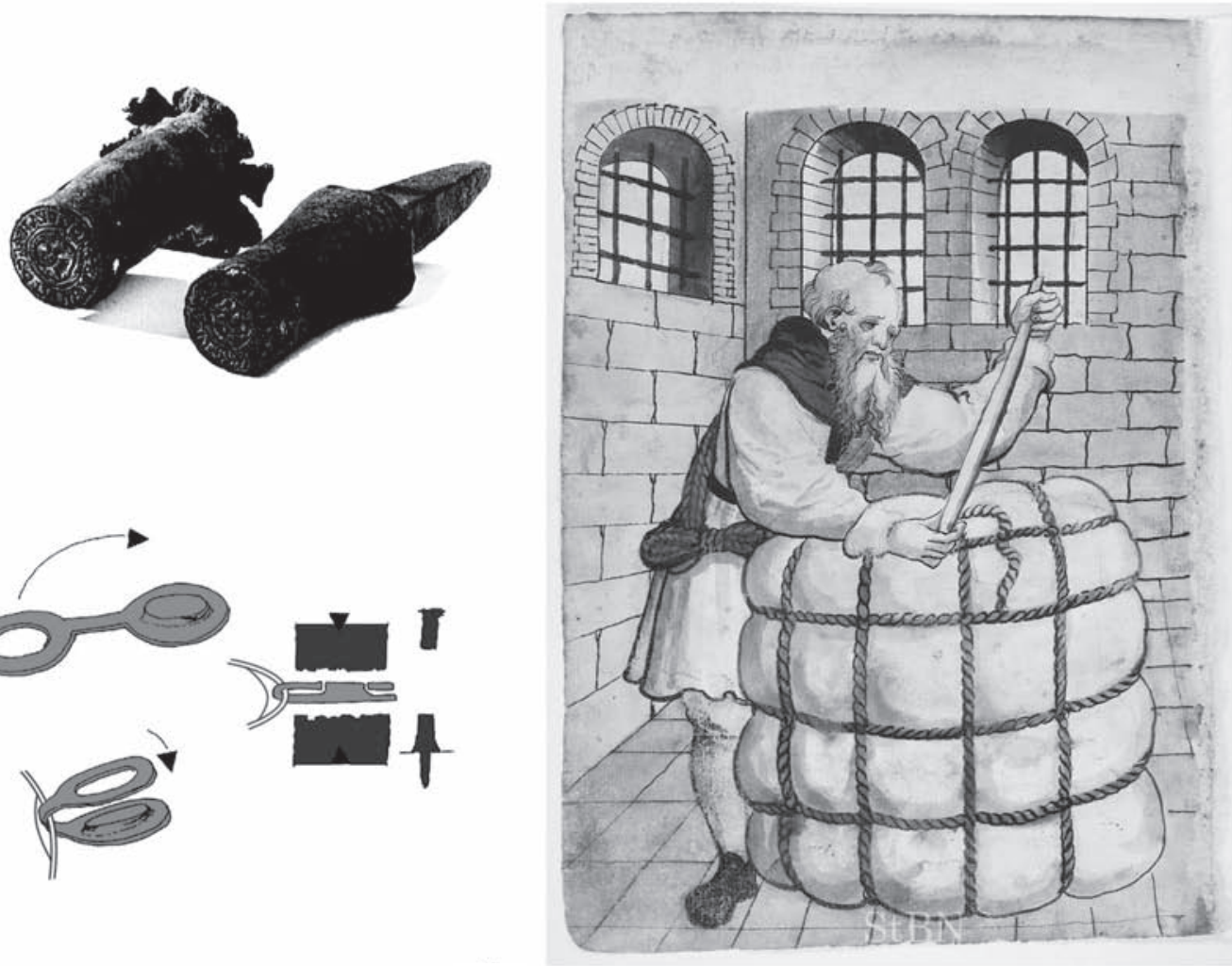

5.

6.

2. kép: A textilplombák és használatuk. 1: A textilplombák Magyarországon is előforduló típusai (Egan 1994, viii alapján); 2: 17. századi "nyers" plomba Rotterdamból (http://collectie.museumrotterdam.nl/objecten/8842; Museum Rotterdam 8842); 3: Leideni plombapecsételő fogó (Rodenburg 2007, 52 ill 10.); 4: Zsinórra felfüzött posztóplombák (Friziában elökerült, Tangermündből származó plombák. Megtalálója: Earl Specht, http://wf4.nl/paginaEarl/earllakenloden.htm); 5: Üllös posztópecsételő és használatának módja (Schütte 1993, 137 Abb. 3.); 6: Bálázó mester Nürnbergből („pallen pinder" 1533. Hausbuch der Mendelschen Zwölfbrüderstiftung, Band 1. http://www.nuernberger-hausbuecher.de/75-Amb-2317-148-v/data) (Stadtbibliotek Nürnberg) 
mennyiségben rendeltek ólomplombát: 1304-1305-ben 12500, a következő évben pedig már 30000 darabot. Ez a mennyiség fokozatosan emelkedett, és 1314-1315-ben már 63500 darab beszerzéséről számolnak be a városi számadáskönyvek.23 Ezek adatait összesítve 1304-1384 között összesen 4.262.605 plombát, 920 pecsételő fogót és 26 kalapácsot rendeltek. ${ }^{24}$

Az ólomplombák alkalmazása minőségjelzőként viszonylag gyorsan elterjedt egész Nyugat-Európában. A régészeti leletanyag csak kiegészíti az írott forrásokból már régóta ismert képet. Így tudjuk, hogy a legnagyobb német posztógyártó központok - többek között Nürnberg és Frankfurt - a 15. századtól biztosan használtak ólomplombákat. ${ }^{25}$ A magyarországi forrásokban a legkorábbi bélyegzésre utaló adat 1444-ből származik, a brassói gyapjúmüveseknek szóló oklevélben. ${ }^{26}$

A nagyon részletes és többlépcsős szabályozás - amint ezt Geoff Egan ki is emeli - elméletben azzal járhatott, hogy minden egyes posztóvégre, mire az a piacra került, akár 5-6 plomba is felkerülhetett. ${ }^{27}$ Több olyan, fennmaradt példa ismert, amikor ténylegesen is több plomba látható egy-egy posztószegélyen ${ }^{28}$, vagy lóg a posztóbálázó zsinóron (2. kép 4.), általánosságban a gyakorlat mégis egyszerűsödött, már csak azért is, mert nagyobb szállított textilmennyiség esetén a sok ólomplomba aránytalanul és feleslegesen nagy súlyt jelentett volna. A posztógyártó városokban az ellenőrzés úgy történhetett, hogy az egymást követő lépések pecsétjei egymást váltották fel, s a korábbi pecséteket leszedték. Így a legutoljára felkerülő, már egyedüli plomba igazolta, hogy minden megelőző lépcsőfok is megfelelt az előírásoknak. Leszedve a feleslegessé váló pecséteket, azok anyagát újrahasznosították, ezzel jelentős mennyiségü nyersanyagot is megtakarítva. ${ }^{29}$ Mindennek ugyanakkor régészetileg az a következménye, hogy a posztógyártó központok területén többnyire másfajta plombákra kell számítanunk, mint amilyenek az ugyanazon helyekről származó, de a távolsági kereskedelembe belekerülő posztóval terjedtek.

A kereskedelembe bekerülő textileken általában kétféle jelzésnek kellett szerepelni. Ezek akár ugyanazon a plombán is előfordulhattak, de lehetett két különböző darab is. Az egyik jelzés a posztó fajtáját jelezte. Ez a legtöbbször a készítő jelzésével is összekapcsolódott, s célja elsősorban a gyártó azonosíthatósága volt az ellenőrzés folyamata során. A második jelzés már kifejezetten „minőségigazoló” funkcióval rendelkezett, biztosítékot adva a vásárlónak, hogy az adott termék átment az előírt ellenőrzések sorozatán. Az egyik legnagyobb holland textilkutató, Nicolaas Wilhelmus Posthumus, aki a 20. század elején feldolgozta a leideni posztógyártás hatalmas levéltári hagyatékát ${ }^{30}$, kimutatta, hogy a plombák méretbeli eltérése is minőségjelző. A nagyméretű darabok csak a legjobb minőségű posztóra kerülhettek, a másodvonalbeli textilt kisebb méretű ólomjelzésekkel látták el. ${ }^{31}$ Öszszefoglalva - a nemzetközi kereskedelembe bekerülő posztón lévő plomba azt jelezte, hogy az adott termék a készítés helye által támasztott mindenféle (minőségi, méretbeli, színbeli és sűrűségbeli) elvárásnak megfelelt. ${ }^{32}$

A plombák minőségjelző szerepének komoly jelentőséget tulajdonítottak. Jól jelzik ezt a hamisítási kísérletek is. Ezeket többnyire különféle újabb szabályozások, újfajta pecsétképek bevezetésével próbálták rendezni. Sankt Gallen jó minőségű termékeinek és eredetjelzésének utánzását a 15. század elején még sikerült visszaszorítani. ${ }^{33}$ A 14. század folyamán a leideni polgárok számos alkalommal emeltek panaszt, hogy plombáikat mind a vidéki posztókészítők, ill. más városok - legfőképpen Hága - mesteremberei utánozzák. Miután többször is hiába igyekeztek megoldást találni, végül a Hanza-városok többsége 1465-ben bojkottba kezdett Hága ellen. ${ }^{34}$ Saint-Omer termékeinek utánzása és a város pecsétjével való ellátása az 1360-as években már fegyveres konfliktushoz vezetett. ${ }^{35}$ Előfordultak olyan esetek is, amikor a város polgára a saját városának bélyegét hamisította. A legsúlyosabban a kölni végződött 1433-ban, amikor a városi tanács máglyán égettette el a bűnbe esett takácsot. ${ }^{36}$ Ypernből pedig hasonló vétekért "csak" hét évre száműzték az érintettet. ${ }^{37}$

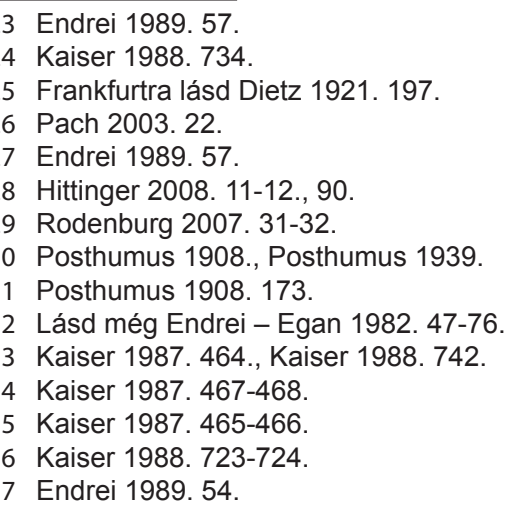




\section{A textilplomba mint régészeti lelet}

A magyarországi ásatásokon előkerülő ólomplombák szinte minden esetben használt, leszakított, deformált vagy töredékes darabok (pl. 5. kép). A leszedés kétféle módon történhetett: szerencsés esetben azt a spárgát vágták el, amelyhez a plombát rögzítették, így azok viszonylagos épségben, lepecsételéskori állapotukban kerülnek elő (pl. 5. kép 1., 3-4., 6., 8.). Rosszabb esetben a plombát nyitották fel, csavarták le, szakították el. Az utóbbi jelentősen megnehezíti utána a darabok visszaazonosítását, föleg, ha a plomba több részre tört.

A korabeli textilgyártásban többféle plomba létezhetett. ${ }^{38} \mathrm{~A}$ magyarországi leletanyagban eddig azonban csak két változat fordul elő. Az első és a leggyakoribb az angol terminológia alapján szegecses plombának nevezhető (rivet seal). A neve jelzi a legfontosabb tulajdonságát: keskeny szalaggal összekapcsolt két korongból állt, melyek közül az egyiken kerek lyuk volt, másikból pedig kisebb nyúlvány - szegecs - állt ki (2. kép 1-2.). A posztógyártó központokban viszonylag sok ilyen, még használatlan darab került elő, mint a képen (2. kép 2.) látható rotterdami példa, de Angliából is ismertek hasonló leletek. ${ }^{39} \mathrm{~A}$ posztó lepecsételése során ezt félbehajtották, a szegecs átment a posztó szegélyén (!) és a másik korong kerek nyílásán, majd az egészet valamilyen módon összezárták. ${ }^{40} \mathrm{Az}$ összezárásnak is legalább kétféle módja lehetett. Úgy túnik, hogy korábbi lehetett az, amikor pénzveréshez hasonló módon verték a pecsétet. llyenkor két verőtő közül az egyik üllöként szolgált, a másikra pedig ráütöttek. Mindkét verőtövön vésett minta volt. Ilyen típusúak a göttingeni posztócéh 16. század második feléből fennmaradt verőtövei (2. kép 5.). ${ }^{41}$ A pecsételés másik módja már egyszerủbb volt: egy fogó pofáit alakították ki olyan formájúra, hogy a plomba összepréselése során elfogadhatóan olvasható nyomot hagyjon. Ilyen fogó maradt fenn a leideni posztómúzeumban (2. kép 3.) ${ }^{42}$, egy másik, 1608-as évszámmal Thonderben ${ }^{43}$, de egy amszterdami ásatáson is előkerült hasonló, az 1350-es évekre keltezhető fogó. ${ }^{44}$

A pecsételés során a szegecs összenyomódott, kilapult, összekapcsolódva a másik koronggal. A legtöbb ilyen darabon világosan felismerhető a szegecses és a lyukas korong. Eddig nem sikerült semmiféle következetességet megfigyelni abban, hogy melyik pecsét a plomba melyik oldalára került.

A középkor végétől, főleg az angol területeken egy-egy ilyen plomba már akár négy-hat kisebb, összekapcsolt korongból is állhatott, így egyetlen darabra kerülhetett fel az összes szükséges információ. ${ }^{45}$ Ilyen összetett plombákból Pápáról egyetlen egy darab ismert, de az eredete még bizonytalan.

A második típus az elsőben csak annyiban tér el, hogy a szegecs két nyúlvánnyal rendelkezik, s ennek megfelelően két nyílásba illeszkedett, s így lapították össze. Ilyen megoldást eddig elsősorban a Tournai-i daraboknál lehetett megfigyelni (6. kép 3.).

A harmadik, Magyarországon is előforduló típusnál a két kerek rész eredetileg is tagolatlan, vagyis szegecs, illetve kerek lyuk nélküli. Ezek általában nagyobb méretű, igényesebb darabok voltak (4. kép 3., 6. kép 2.).

\section{A textilplombák kutatása Magyarországon}

Az ólomplombák kutatása Magyarországon éppenhogy eléri a minimális szintet, aminek egyértelműen objektív okai vannak - a fémkereső aktív használata előtt ezek a leletek csak nagyon ritkán kerültek elő, ugyanis földes állapotukban alig különböznek a kavicsoktól. Ezt a pápai ásatás során személyesen is megtapasztaltuk. A 135 darab mindegyike fémkeresővel került elő, egyetlen egyet sem vettünk észre még a legfinomabb padlótisztító munkák során, legtapasztaltabb emberekkel sem. (Összehasonlításképpen: a kb. 730 darab előkerült érméből kb. 200 darabot találtuk meg mi, a többit szintén fémkereső segítségével. ${ }^{46} \mathrm{~A}$ legtöbb országos gyűjiteményben csak néhány darabot találunk a régebbi ásatásokból, ezek is többnyire nagyobb méretú leletek. ${ }^{47} \mathrm{~A}$ legnagyobb gyarapodás az elmúlt tíz év illegális kincskereső tevékenysége nyomán történt lefoglalások, illetve kisebb mennyiségben ajándékozás révén is történt. Így pl. a Magyar Nemzeti Múzeumban lévő középkori és kora újkori ólomplombák száma ma már eléri a 100 darabot. Összességében jelenleg a Kárpát-medencéből - a pápai leleteken kívül - kb. 200 textilplomba ismert a múzeumi gyűjteményekben. Ehhez viszonyítva a pápai majd' másfélszáz darab igen jelentős mennyiségnek tekinthető. Ráadásul a legtöbb múzeumi darabtól eltérően a pápaiak nagy többsége réteghez köthető, sok esetben pénzzel keltezett lelet. Ezek mellett tudomásunk van több, kisebb-nagyobb magángyűjiteményről is, azok nagysága azonban még csak meg sem becsülhető. Valamit sejtet az a tény, hogy a Kaposváron 2003-ban lefoglalt anyagban

38 Hittinger 2008. 9 .

39 Egan 1978. 179.

40 Hittinger 2008. 8., 11-12.

41 Schütte 1993. 137. (Abb. 2-3).

42 Rodenburg 2007. 52., ill. 10.

43 Hittinger 2008. 10.

44 Gawronski 2009. 24.

45 Egan 1978. 178., Egan 1992. 11., 13.

46 Ezúton is köszönetet mondok Sándor Lajosnak, aki a fémkereső-műszeres kutatásokat végezte.

47 Ilyeneket dolgozott fel pl. Huszár Lajos is: Huszár 1961. 

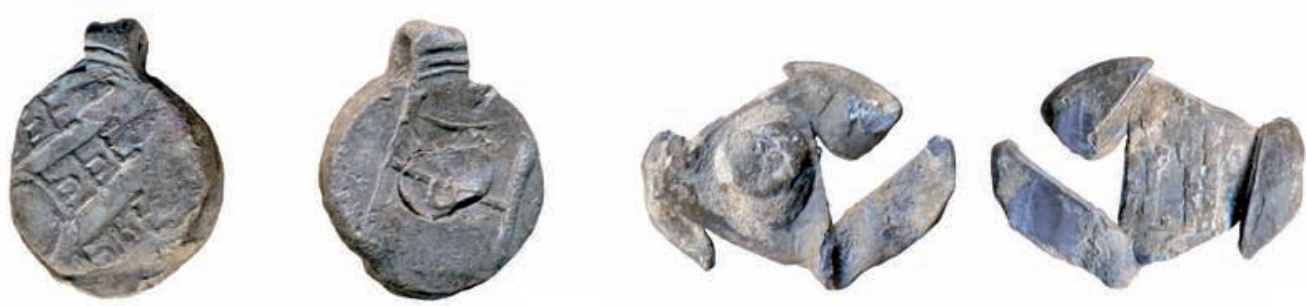

1.

2.

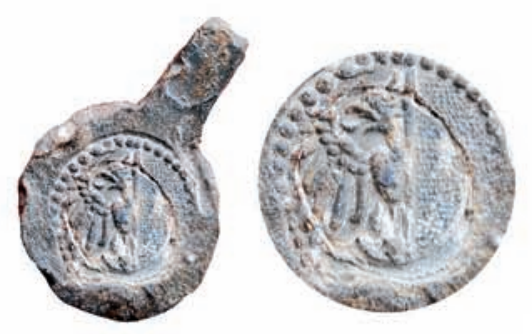

3.
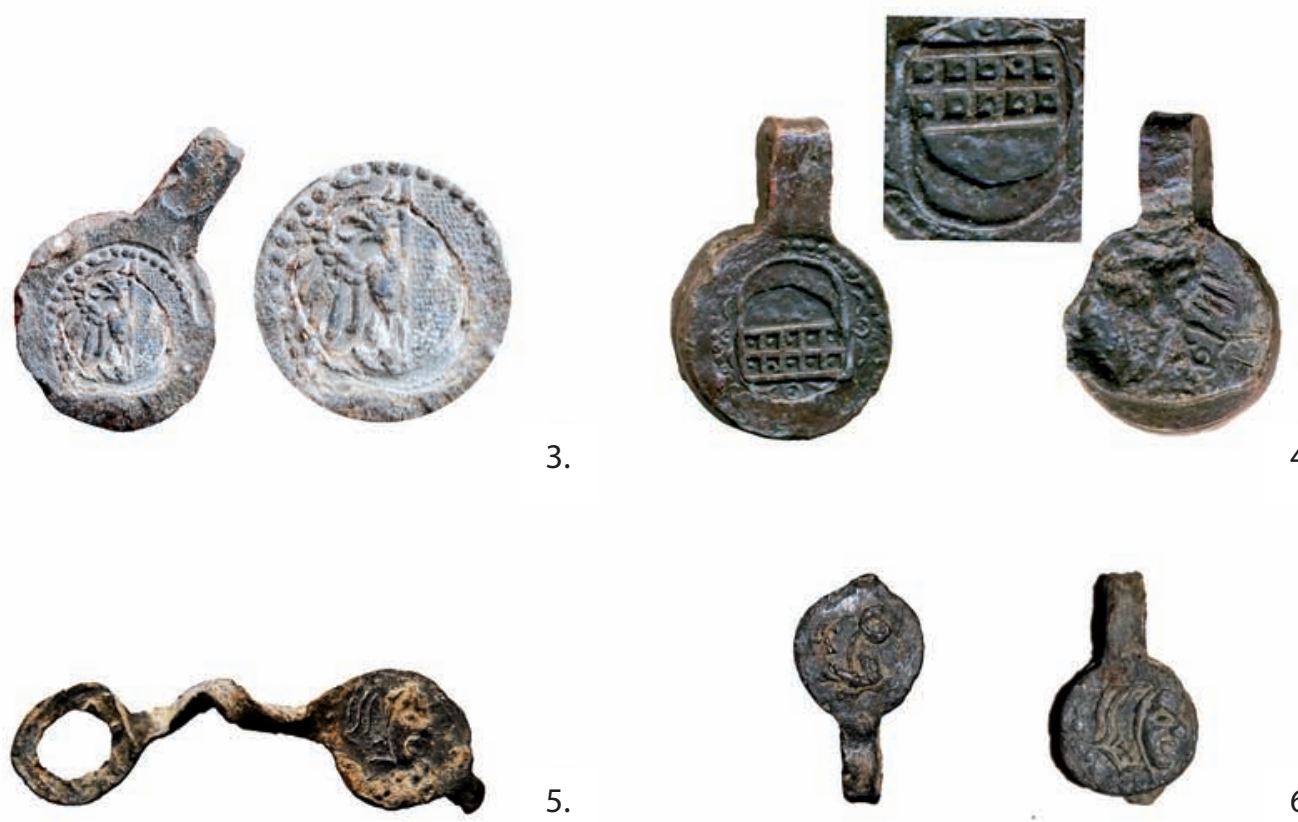

5.
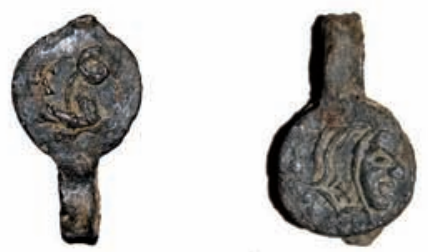

6.
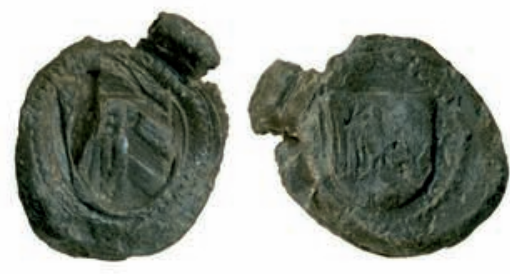

7.
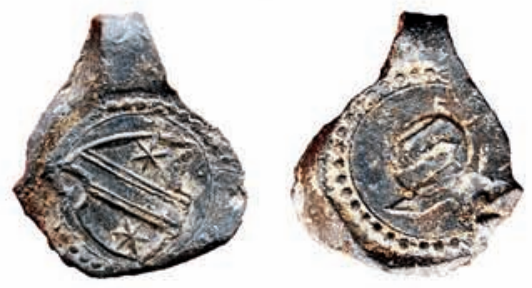

8.

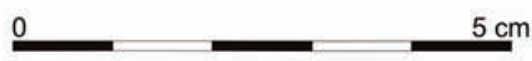

3. kép: Válogatás a pápai Fő tér textilplombáiból. Németországi plombák: 1-2: Hamburg (VI/18, SNR-2761; VI/25, SNR-2235); 3-4: UIm (VI/2-4, SNR-2007; IV. felület SNR-1005); 5-6: München (III. felület SNR-1005; VI/3, SNR-2443); 7 : Nürnberg (VI/7, SNR-2311); 8: Kaufbeuren (VI/6, SNR-2399) 

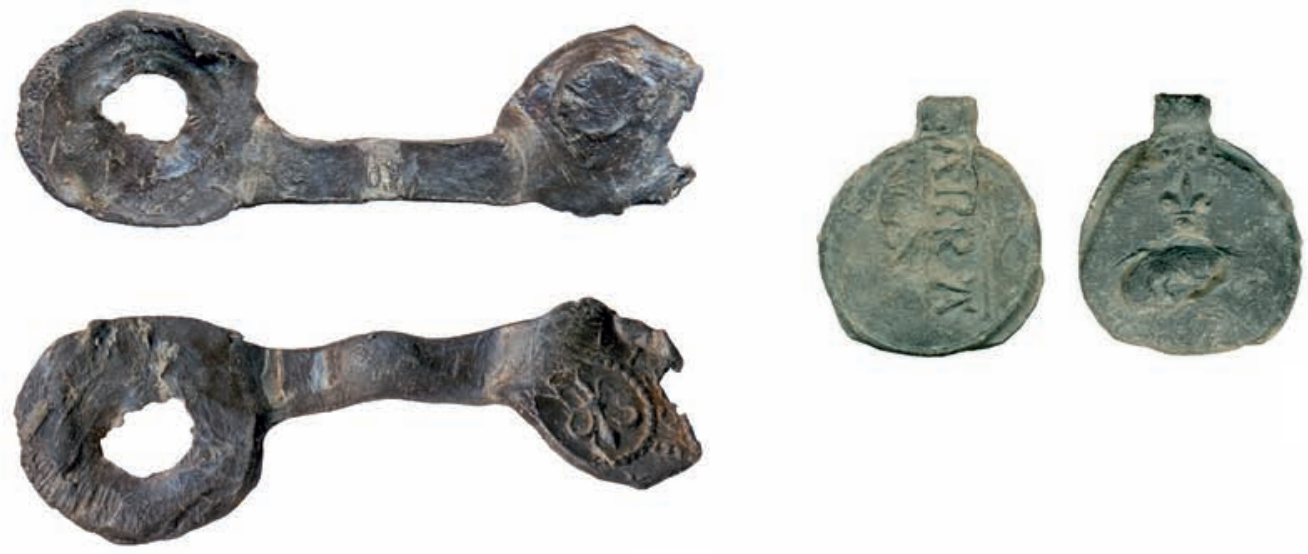

2.

1.
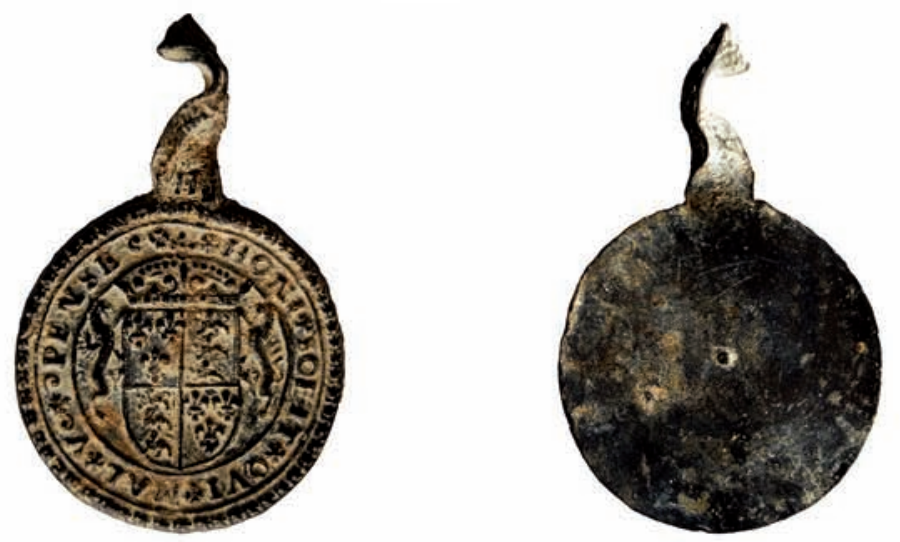

3.

HONI *SOEIT * QVI * MAL * Y * PENSE *
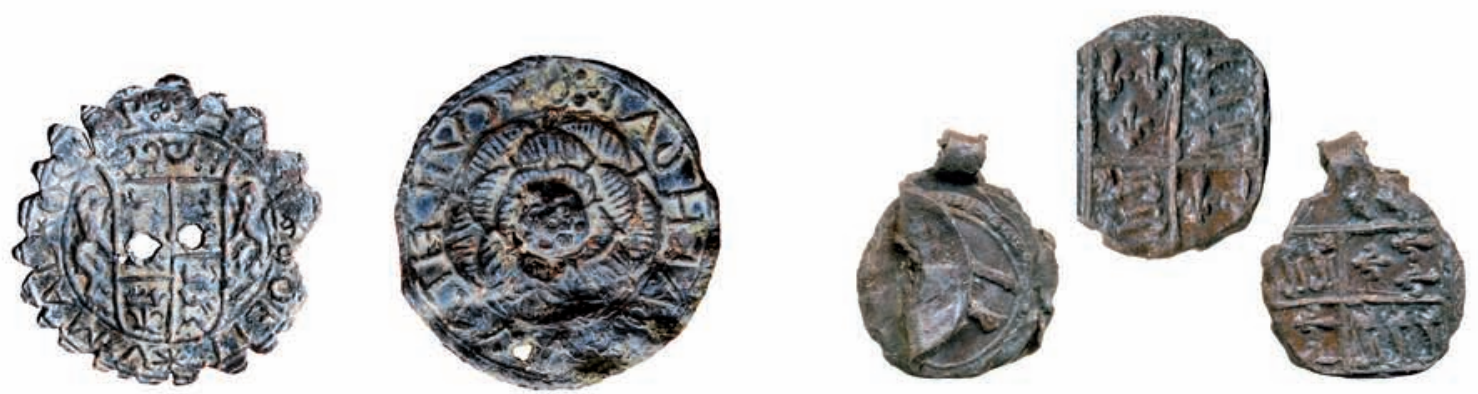

4.

5.

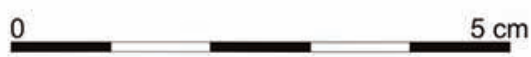

4. kép: Válogatás a pápai Fő tér textilplombáiból. Németalföld és Anglia. 1: Lille (VI/41, SNR-3375); 2: Arras (VI/41, SNR-3341); 3-5: Anglia (VI/35, SNR-2235; VI/16-21, SNR-2128; VI/30, SNR-2414) 
kb. 70 darab van, vagyis több, mint amennyi addig az ország összes múzeumában együttvéve volt!48

A Magyarországról ismert plombák mennyisége arányaiban mostanra már kezd megfelelni a nyugat-európainak. Ugyan a londoni több mint 10000-es és az amszterdami 1500-as darabszám elérésére egy darabig kevés az esély, de például összehasonlítva a Braunschweig környékéről (441 darab), Trierből (200 darab), Brémából (187 darab), Lübeckből (110 darab) vagy Gdańskból (60 darab) ${ }^{49}$ előkerült mennyiséggel, a pápai plombák száma talán még aránytalanul magasnak is túnhet.

A témához kapcsolódó legkorábbi tanulmányok és feldolgozások Huszár Lajos és Endrei Walter neveihez köthetők. Az előbbi a numizmatika, az utóbbi pedig a posztógyártás történetének irányából közelítette meg a kérdést. Huszár Lajos elsőként hívta fel a nemzetközi szakma figyelmét az angol címeres posztóplombákra, és összegyűjtötte az addigra Magyarországon ismertté vált hasonló leleteket. ${ }^{50}$ Endrei Walter további itáliai és németalföldi darabokat is közölt, de kitért a posztópecsét magyarországi használatára is. ${ }^{51}$ Emellett a nemzetközi kutatásokba is bekapcsolódott a textilplombák legnagyobb nemzetközi kutatójával, Geoff Egannal. Közös tanulmányukban éppen a posztópecsétek használatáról értekeztek. ${ }^{52} \mathrm{Az}$ utóbbi években a szlovák területek textilplombáinak feldolgozása haladt egyre jobban Jan Hunkának köszönhetően. Legfontosabb munkájában a szlovákiai gyüjteményekből eddig ismert darabokat dolgozta fel..$^{53}$

Endrei Walter mellett a források feltárása Székely György és Pach Zsigmond Pál ${ }^{44}$ neveihez kapcsolhatók, akik a téma történeti feldolgozását végezték..$^{55}$

\section{Pápai plombák és kapcsolataik}

A pápai plombák térben és időben is elég nagy távolságokat ölelnek át. A legkorábbi posztópecsétek Zsigmond pénzeivel keltezett rétegekből származnak, s úgy túnik, hogy vannak 18. századi darabok is. Térben pedig a leletek a Németalföldtől Morvaországig terjedő központokból származnak. Különleges csoportot alkotnak az angol címeres darabok. Mivel a jelenlegi tanulmány keretei nem teszik lehetővé, csak az egyértelmű, látványosabb darabokat ismertetném külön.

A magyarországi előforduló legkorábbi plombatípusok Pápán nem kerültek elő. A kép teljességének kedvéért itt kitérnék ezekre. A jelenlegi ismereteink szerint a legkorábbi darabok Németalföldről származnak. A Visegrádon talált tournai-i eredetű darab a 14. század második felére keltezhető. ${ }^{56} \mathrm{~A}$ zólyomi Pusztavár felső várában, a ciszternából került elő még egy hasonló darab. Ezt is a 14. század második felére keltezik. ${ }^{57}$ Ez a leggyakoribb magyarországi plombatípus, így a Magyar Nemzeti Múzeumban lévő Sándor Lajos-féle gyűjtésben (6. kép 3), a Korinek-féle gyűjteményben (Kacsóta, Bóly és egyéb Baranya megyei lelőhelyek) és a Kaposváron 2003-ban lefoglalt leletegyüttesben is ebből van a legtöbb. Ugyanilyen méretű és címerképű plomba Európa számos lelőhelyén előkerült, így pl. a nyilvánvaló németalföldi lelőhelyeken túl, Londonban, Turkuban (Finnország), Novgorodban és Svédországban is. ${ }^{58} \mathrm{Az}$ utóbbi helyen (Lund) ugyancsak a 14. század második felére keltezik..$^{59}$

Pápáról a németalföldi posztógyártásra egyedül Lille (4. kép 1.) posztópecsétjei utalnak. Ezeket I. Ferdinánd pénzei keltezik. Ezzel nagyjából egykorú a már artois-i Arras plombája (4. kép 2.). Még belsőbb franciaországi területekről származnak Beauvais és Provins ólomplombái. Közülük a beauvais-i darab egy Zsigmond pénzzel keltezett rétegből származik, a másik pedig szórvány.

Mivel eddig egyiknek sem ismert magyarországi analógiája, az azonosításuk az arrasi darab esetében a felirata, a másik kettőnél pedig a címer alapján történt. A lille-i posztó azonosítása kevésbé biztos, ugyanis a liliom elterjedt címerkép volt a késő középkori Flandriában. ${ }^{60}$

Északnyugat-Európánál maradva ki kell emelni a külön csoportot alkotó, angol címeres plombákat. Az öszszes textilplomba közül ez a legjobban kutatott és ismert típus, de valójában a 16. századi darabokon belül ez tekinthető a legelterjedtebbnek is. Már Huszár Lajos is legalább 13 darabot gyűjtött össze Magyarország legkülönbözőbb helyszíneiről: számos várból (Eger, Győr, Buda, Nagykanizsa, Nagyvázsony), illetve Túrkeve-Móric te-

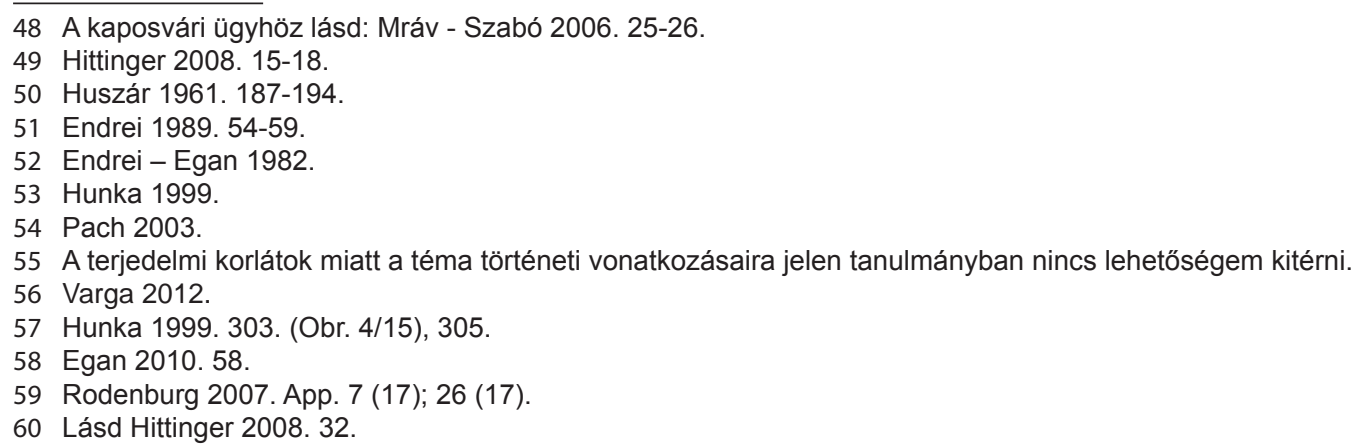


rületéről. ${ }^{61}$ Ez kiegészíthető több újabb lelettel, többek között Vácról ${ }^{62}$, Bajcsáról ${ }^{63}$, Tamási határából ${ }^{64}$, Varjasról ${ }^{65}$, Nyitráról és Sztrecsnóról. ${ }^{66}$ Számos további, ismeretlen lelőhelyű darab került a Magyar Nemzeti Múzeumba az elmúlt évtizedben (Id. pl. 6. kép 1-2.). A típus szinte minden esetben két részből állt. Az egyik korongon Anglia 1603 előtti címere szerepel, királyi koronával, címertartó állatfigurákkal. Általában körirat is látható: $H O N * Y *$ SOEIT * QUI *MAL * $Y * P E N S E$, illetve ennek valamilyen rövidített vagy torzult változata. A másik oldalon Tudorrózsa szerepel, általában szintén körirattal. Ennek a szövege nagyobb mértékben változhatott és sok kérdést vet fel: $+Q V I L L E L M U S+Q^{*} Q+A L M A N D E T E E+Q^{*}$. Az első egyértelmúen az angol címerhez tartozó hivatalos mottó, míg a másodikat „Német Vilmos"-ként tudjuk lefordítani, ami nyilvánvaló ellentétben áll az angol címerrel. Külön meg kell említeni, hogy a Magyar Nemzeti Múzeumba mostanában bekerült két ilyen, a Dunántúlról származó, jó megtartású, kétoldalas posztóbélyeg egyik oldalán sincs semmilyen felirat, s valószínűleg nem is volt (6. kép 1.).

Magyarországon kívül ilyen plombák még számos európai országban előkerültek, csak éppen Angliából nem ismert egy sem. A legnyugatibb darabok Amszterdamból származnak, még a legkeletibbek Vilniusból ${ }^{67}$, Novgorodból és Kijevből.68 A két ismert évszámos darab egyike - Tudor-rózsa "VILHELMUS * ALMANDETE 1583" körirattal Lundban (Svédország) került elő, míg a vele teljesen megegyező másik a csehországi Prostějovból. ${ }^{69}$ Maga a címer, illetve ennek kisebb mértékben eltérő változatai a kutatások alapján 1558 és 1603 közé keltezhetők. Legmeglepőbb egy észak-dunántúli, ismeretlen lelőhelyű darab a Magyar Nemzeti Múzeumból (Sándor Lajos ajándéka), melynek aranyozták a felületét.

Pápán két ehhez a típushoz tartozó plomba került elö. Az egyiknek csak az egyik oldala maradt meg, mégis ez az egyik legigényesebb kivitelezésű, jó megtartású darab (4. kép 3.). A címer körirata hibátlan, és jól megkülönböztethető a két címertartó állat is (oroszlán és unikornis). A másik plomba két részből állt (4. kép 4.). Az egyiken az előzőhöz hasonló címer és körirat látható, de sokkal elnagyoltabb, a figurák alig felismerhetők. A körirat hiányos: $\mathrm{HONI}{ }^{*} \mathrm{SOEIT} *{ }^{*}{ }^{*} \mathrm{MAL}{ }^{*} \mathrm{OC}{ }^{*} C P *$. A korong széleit hullámosra alakították. A másik részén Tudor-rózsa, szintén elnagyolva és egy hiányos, rosszul írt szöveg látható. A körirat az óra járásával ellentétes irányban, vagyis balról jobbra olvasandó (a betűk egy része is tükrözött). A két rész egymás mellett került elő, de biztosan összefüggött. A korongokon látható nyílások jelezhetik az egykori rögzítés módját. Mindkét angol címeres plomba a nem szegecses típushoz tartozott. Az angol címer egy harmadik, hagyományosabb típusú plombán is előfordult (4. kép 5.). Itt az előlapon a címerpajzson kívül más nem szerepel, a hátoldalon lévő jelzés pedig egyelöre nem feloldható.

A három angol címeres plomba közül az első (4. kép 3.) másodlagos helyzetben volt a 17. századi nagy pincét kitöltő, 18. századi planírozási és bontási rétegében. A második (4. kép 4.) egy II. Rudolf 1581-es érméjével keltezhető rétegből származik, s ezzel jól illeszkedik a korábbi kutatás eredményeihez. A harmadik, kisebb méretű, már inkább a 16. század közepére, I. Ferdinánd pénzeit tartalmazó rétegekhez köthető. Ilyen, kisméretü, angliai posztópecsétek Németországból is előkerültek, Brémából és Stadéből. A pápaihoz hasonlóan ezek is a 16. század középső évtizedeire keltezhetők a rajtuk lévő évszámok - 1553, 1560 - alapján. ${ }^{70}$

Az angol címeres plombatípus eredetéről már Huszár Lajos felvetette, hogy nagy valószínűség szerint nem Angliából származik. ${ }^{71}$ Ezt az elképzelést Geoff Egan is osztja. ${ }^{72}$ Eszerint az ilyen textilplombák olyan angliai eredetú posztóra kerültek, amelyet valahol, talán valamelyik német városban átcsomagoltak. Egy ilyen lelet Antwerpenből megerősíti Egannak azt az elméletét, mely szerint az előkészített angliai posztó nagy mennyiségben került ebbe a városba, ahol megnyírták és befestették, s csak utána dobták piacra. Az, hogy a posztó nyírása térben is határozottan elvált a posztó gyártásától, nagyon sok helyen egyértelműen kimutatható. ${ }^{73}$ A folyamat az írott források alapján nagyon jól követhető, de egyelőre nincs kézzel fogható nyoma annak, hogy az angol címeres plombák erre a textilre kerültek volna rá. ${ }^{74}$

A plombatípus rendkívüli gyakoriságát a Kárpát-medencében a nagyszámú katonasággal magyarázhatjuk, illetve a posztóval való fizetéssel. A tizenötéves háború során pedig egyértelműen megnövekedett a Magyar Királyság területén állomásozó, illetve az azon átvonuló csapatok létszáma. Valószínűleg nem véletlen, hogy az angol címeres plombák többsége a csapatmozgások vonalát és az intenzívebb hadmúveletek helyszíneit jelzi.

61 Huszár 1961. 187-194., Endrei 1989. 56.

62 Tettamanti 1994. 111., 170. (37. tábla 5-6.).

63 Kovács 2002. 179., 207-208. kép.

64 Közöletlen, Korinek-gyűjtemény, Magyar Nemzeti Múzeum.

65 Szolnoki László és Bacskai István szíves szóbeli közlése.

66 Hunka 1999. 303., Obr. 4/10, 14.

67 Kaplūnaitè - Jonaitis 2005. 84-85. (1 pav.).

68 Huszár 1961. 187-194., Hittinger 2008. 61., Egan 2010. 61. Kijevre: Klimovszkij 1997. 50-52., Novgorodra: Janyin 1953.384.

69 Rodenburg 2007. App. 9 (23); 27 (23).

70 Hittinger 2008. 61, 202-203, Taf. 37. 1-5.

71 Huszár 1961. 188.

72 Egan 2010.61.

73 Pach 2003. 41.

74 Egan 2010.61. 

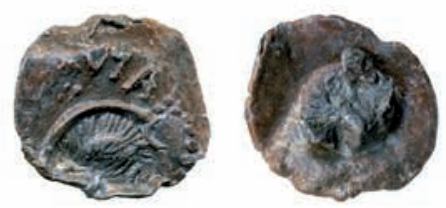

1.
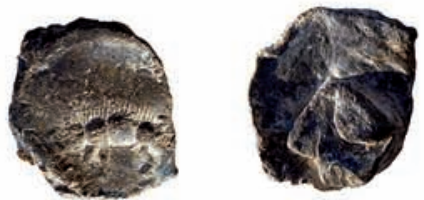

2.
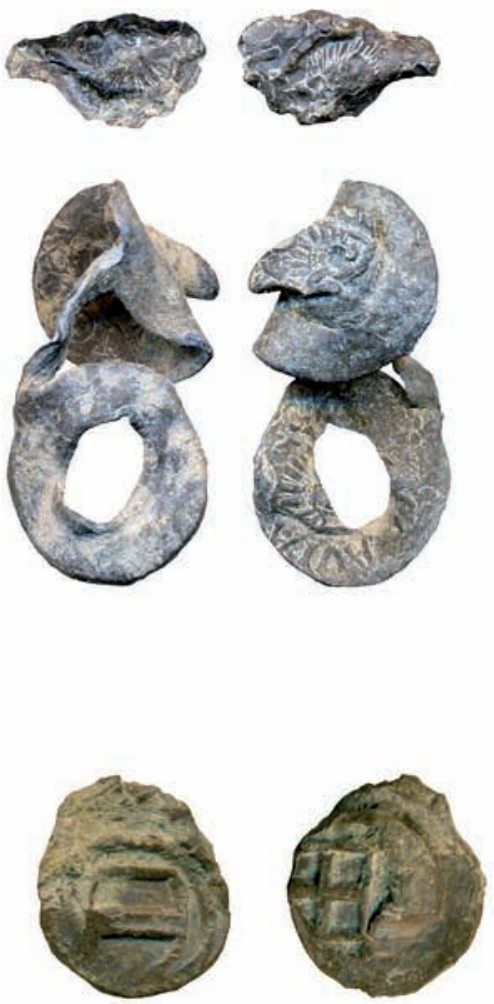

7.

3.
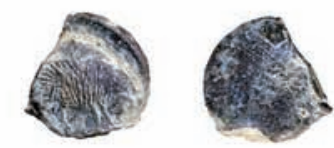

4.
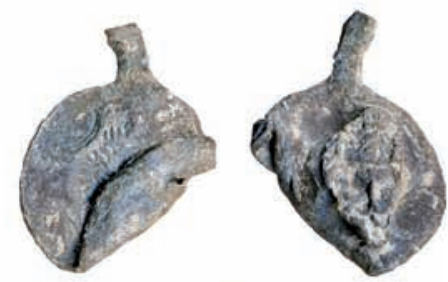

5.

6.
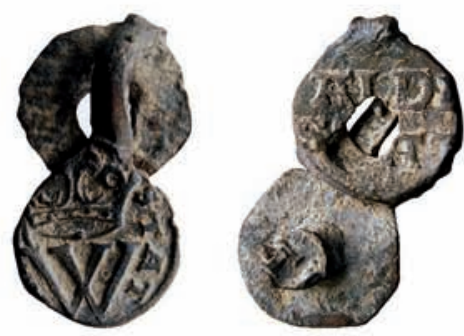

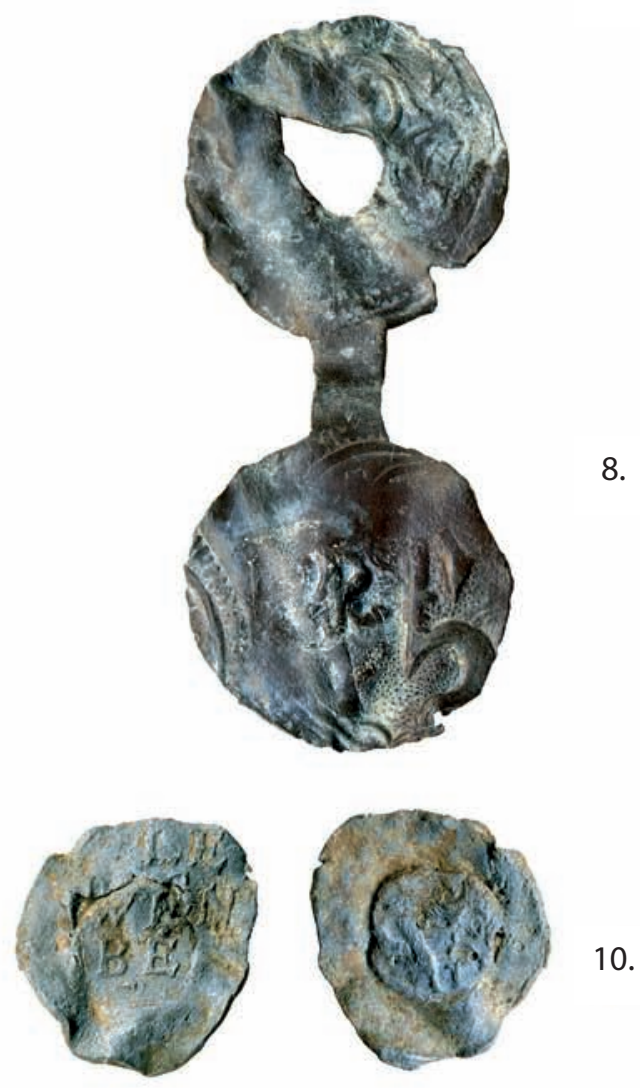

8.

5. kép: Válogatás a pápai Fő tér textilplombáiból. Morvaország, Ausztria és Szilézia: 1-6: Jihlava (VI/46, SNR-1005; VI/42, SNR-3406; VI/38, SNR-2180); 7: Bécs (Wien, VI/10, SNR-2441); 8: Nový Jičín (Neutitschein, VI/38, SNR-2180); 9: Boroszló (Wrocław, VI/41, SNR-3341); 10: Lwówek Ślaski (Löwenberg, VI/41, SNR-3402) 

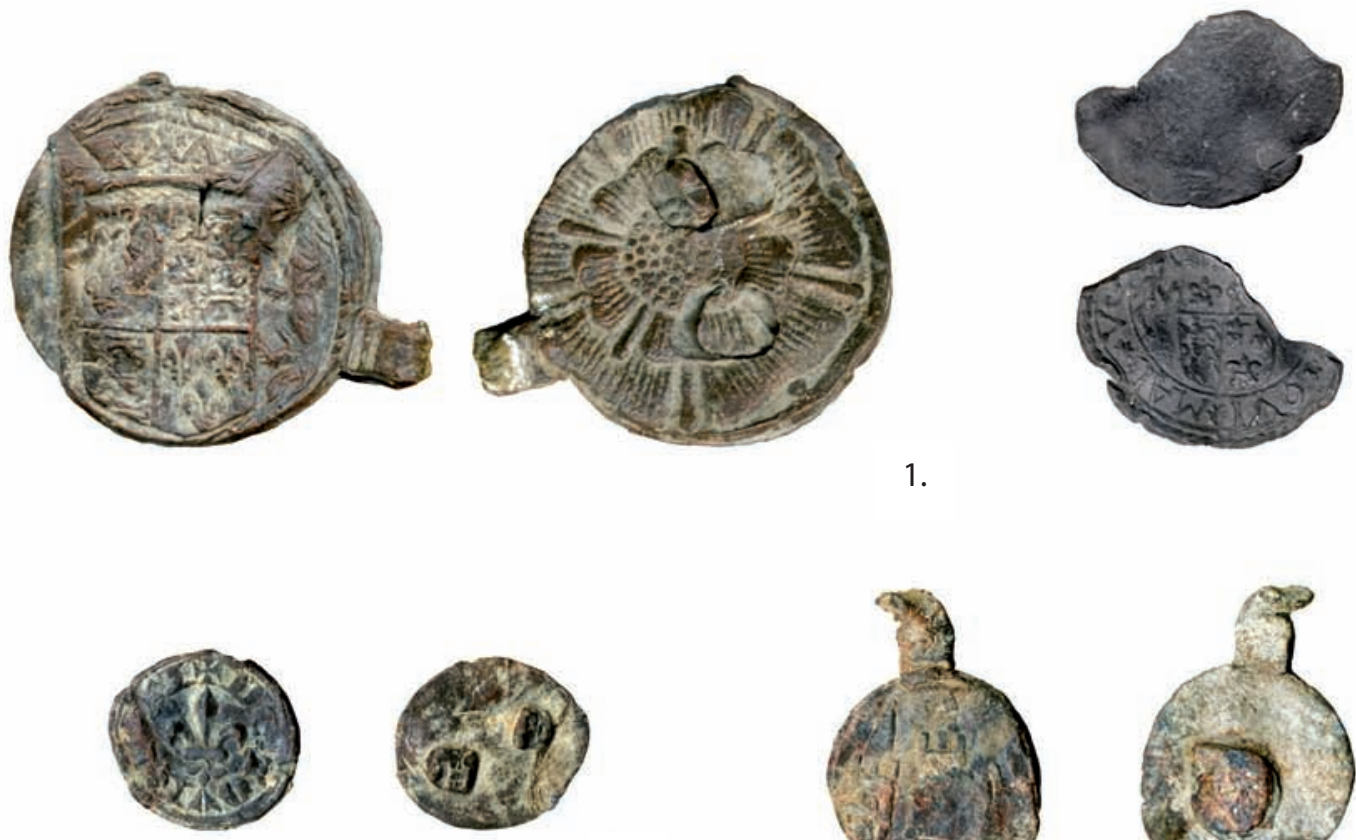

3.
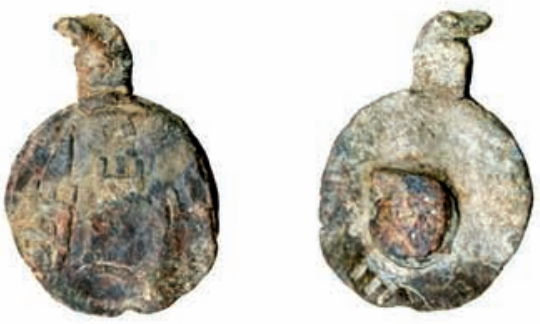

2.

4.
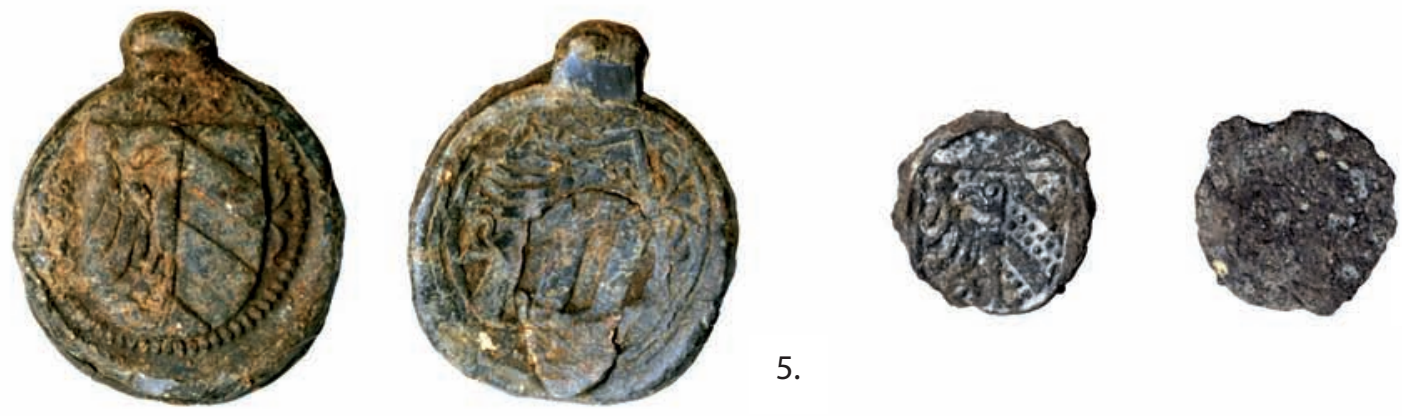

6.

5.
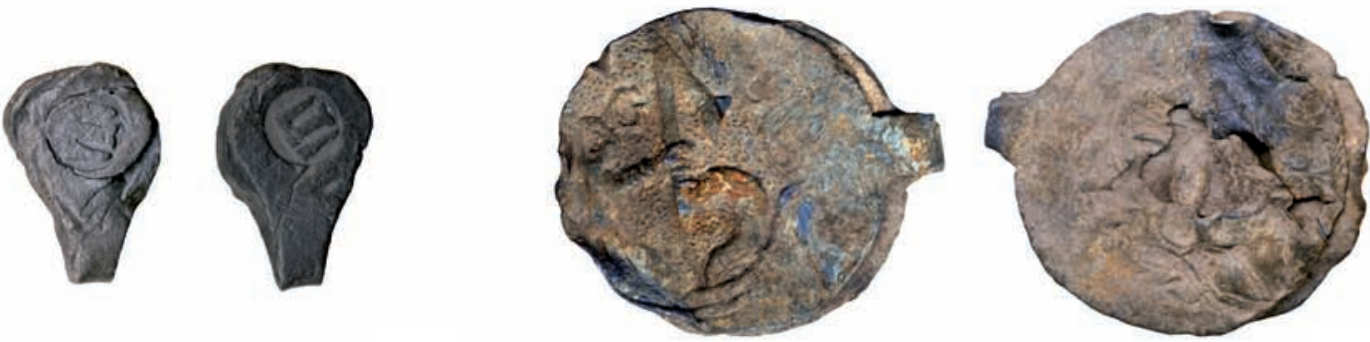

7.

8.

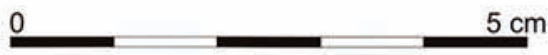

6. kép: Válogatás a Magyar Nemzeti Múzeum anyagából (Sándor Lajos ajándéka, Észak-Dunántúl): 1-2: Angol címeres plombák; 3: Tournai (Belgium); 4: Hamburg (Németország); 5-6: Nürnberg (Németország); 7: Tulln (Ausztria); 8: Nový Jičín (Neutitschein, Csehország) 
A következő nagyobb - és a pápai anyagban legjobban reprezentált - terület a mai Németország. Bátran kijelenthető, hogy a 16. század minden legfontosabb németországi posztógyártó központjából ismert legalább egy posztópecsét Pápáról. A legtöbb plomba öt városhoz köthető: Hamburg (3. kép 1-2.), Ulm (3. kép 3-4.), München (4. kép 5-6.), Köln és Nürnberg (4. kép 7.). További településekről csak egy-két darab ismert: Cottbus, Hanau, Göttingen, Kulmbach. Az utóbbihoz hasonlóan az európai anyagban is egyedülálló még az a plomba, melyet címere alapján Kaufbeuren városához lehet kötni (4. kép 8.). Az esetek többségében a helyszínek beazonosítása a városcímerek alapján történt. Kulmbach és Hanau esetében a plomba felirata kiegészítette és megerősítette az azonosítást. A feldolgozás jelenlegi szintjén a számos pénzzel keltezhető darab közül biztosan kimutatható, hogy az ulmi, cottbusi és müncheni posztó már a 16. század közepén megjelent Pápán. A kölni plombák egyelöre a 16-17. század fordulójától mutathatók ki.

A pápai darabokkal rokon leletek viszonylag kevés helyről ismertek Magyarországról. Eddig néhány nürnbergi és müncheni posztópecsét ismert az egykori Magyar Királyság területéről. Egy müncheni plomba Szitnya várából került elő, 15. századi rétegekből. A pápai darabokhoz hasonlóan itt is a város címerét jelképező szerzetes csuklyás feje látható, profilban. ${ }^{75}$ Nürnbergi plomba a Magyar Nemzeti Múzeumba bekerült számos ismeretlen lelőhelyű (Baranya megye és Észak-Dunántúl) darab mellett (6. kép 5-6.), Bajcsa ${ }^{76}$ és Diósgyőr ${ }^{77}$ váraiból ismert. Az első esetben a leletet a 16. század utolsó harmadára, míg Diósgyőrben a 16-17. század fordulójára lehet keltezni. Sajnos csak szórványként ismert a pápai darabokkal szinte teljesen megegyező címerképú hamburgi posztópecsét (6. kép 4.).

A göttingeni plombák elterjedését külön is vizsgálták, így a németországi mellett ismerünk dániai és svédországi lelőhelyeket is. ${ }^{78} \mathrm{~A}$ hamburgi plombákhoz hasonló címerképű darabok 1535-ös évszámmal jelennek meg Hamburgban és Greifswaldban. ${ }^{79}$ Az ulmi eredetű plombákkal azonos darab került elő Soestból, ahol a 16-17. századra keltezik. ${ }^{80}$ Ugyanakkor figyelemre méltó jelenség, hogy a Dieter Hittinger által feldolgozott leletek között nem találunk olyan, egyértelműen meghatározható címeres darabokat, amelyek megegyeznének a pápai leletekkel.

Még közelebb kerülve az egykori Magyarország határaihoz az akkori szomszédos területekkel - Sziléziával, Cseh- és Morvaországgal, illetve Ausztriával - folytatott posztókereskedelem emlékei kerülnek sorra. A sziléziai területekről két település posztópecsétje került elő: Boroszló (Wrocław, 5. kép 9.) és Lwówek Śląski (Löwenberg, 5. kép 10.). Az előbbi helyszín azonosítása a plombán szereplő „W" alapján feltételezhető, bár az ALDESTAT feliratra a hátoldalon egyelőre nem találtam magyarázatot. Az utóbbiban kis részben a címer, nagyobb részben a felirat segített. Lwówekből legalább három plomba került elő Pápán, míg Boroszlóhoz egyelőre egyetlen egy köthető. Mindegyik sziléziai eredetű plomba I. Ferdinánd pénzeivel keltezhető rétegekből származik. Egyik plombatípushoz sem ismerek egyelőre analógiát.

Cseh-és Morvaországból két fontos kora újkori textilgyártó központ képviselteti magát a pápai leletanyagban: Jihlava és Nový Jičín (Neutitschein). Az összes pápai plomba között az ulmi darabok mellett a jihlavaiak szerepelnek a legnagyobb mennyiségben. Mindkét típus egyértelműen beazonosítható a városok címerképei alapján. A jihlavai darabok sünábrázolása mellett néhol kivehető a JIHLAVIA körirat is (5. kép 1-6.). A jičíni plombákon nagyon különleges címer látható: egy felhőből kinyúló, fél nyilat tartó kar (5. kép 8.). Érdekes, hogy az összes jičíni lelet olyan rétegből származik, amelyben volt jihlavai plomba is. Ezek mind az 1530-as és 1580-as évek közötti időszakra keltezhetők. Magyarországi vagy akár külföldi analógiái ezeknek a plombáknak gyakorlatilag nem ismertek. Egyetlen, ismeretlen lelőhelyú, jičíni posztóbélyeg található a Magyar Nemzeti Múzeumban (6. kép 8.). Feltehetően egy jihlavai darab van a Budapesti Történeti Múzeum gyűjteményében. Ez 1951-ben került elő a budavári szárazárok 15. századra keltezett betöltéséből. ${ }^{81}$

Ausztriából a pápai anyagban csak bécsi plombák fordulnak elő. Ezek könnyen azonosíthatók a tartomány és a város címere alapján (5. kép 7.). Amint feljebb olvasható, a bécsi kapcsolat már az írott források alapján is biztosan igazolható volt. Az előkerült plomba annyiban módosítja a korábbi ismereteinket, hogy a lelőkörülményei - 15. század második fele - legalább fél évszázaddal korábbra teszik ennek a kapcsolatnak a kezdeteit. Magyarországról még két bécsi posztópecsétről van tudomásom, az egyik a Budapesti Történeti Múzeumban ${ }^{82}$, a másik pedig a Magyar Nemzeti Múzeumban van. Az utóbbi a Korinek-féle gyűjteményben Baranya megyei leletként szerepel. Egy további olyan osztrák település is van, melynek posztótermékei eljutottak az Észak-Dunántúlra: Tulln városának címerével ellátott plombák láthatók a Magyar Nemzeti Múzeum gyújteményében. A plombák azonosítása az ausztriai analógiák alapján lehetséges, máshonnan hasonló darabokat

75 Hunka 1999. 300., 302. (Obr. 3/4).

76 Kovács 2002. 179. (206. kép).

77 Huszár 1972. 43-47.

78 Schütte 1993. 137-140.

79 Hittinger 2008. 26., 138., Taf. 9. 1-3.

80 Hittinger 2008. 29-30., 144., Taf. 11. 7.

81 L.sz.: 52.748. Itt és a többi darabnál Kovács Eszternek köszönöm a lehetőséget, hogy megtekinthettem a közöletlen darabokat.

82 L.sz.: 82.575. 
nem ismerek. A Schrattenstein várából származó, egyikT-jelzésű posztópecsét hátoldalán egy pegazus figurája látható. ${ }^{83}$ Egy nagyon hasonló, de az előlapján eltérő ábrázolással rendelkező plomba került elő Pápáról is, így kézenfekvő lenne ebben az esetben is tullni eredetet feltételezni.

\section{Összefoglalás}

A jelen tanulmány szűk kereteihez képest is jól látható, hogy a pápai plombák mekkora óriási lehetőséget rejtenek magukban, hogy végre behozzuk a nyugati kutatásokhoz viszonyított hatalmas lemaradást. Már az előzetes feldolgozás során is számos olyan nyugati posztógyártó központtal való kapcsolatot sikerült igazolni, amelyről az írott források hallgatnak (pl. Kaufbeuren, Lwówek Śląski, Cottbus stb., 7. kép). A leletanyagban még nagy számban vannak olyan plombák, melyeket egyelőre nem sikerült beazonosítani. Mivel az írott forrásokból tudjuk, hogy a 15. század közepétől biztosan használtak Magyarországon is posztópecsétet, sőt az 1556. évi kolozsvári szabályozás még azt is előírta, hogy "legyen rajta a hely és a készítő pecsétje"84, így nem zárhatjuk ki, hogy - amint azt már Jan Hunka is felvetette ${ }^{85}$ - vannak a pápai darabok között magyarországi eredetú plombák is. Ezt a vizsgálatot kell kiegészíteni a történeti forrásokkal való összevetéssel. Ez azonban már egy nagyobb tanulmány feladata lesz.

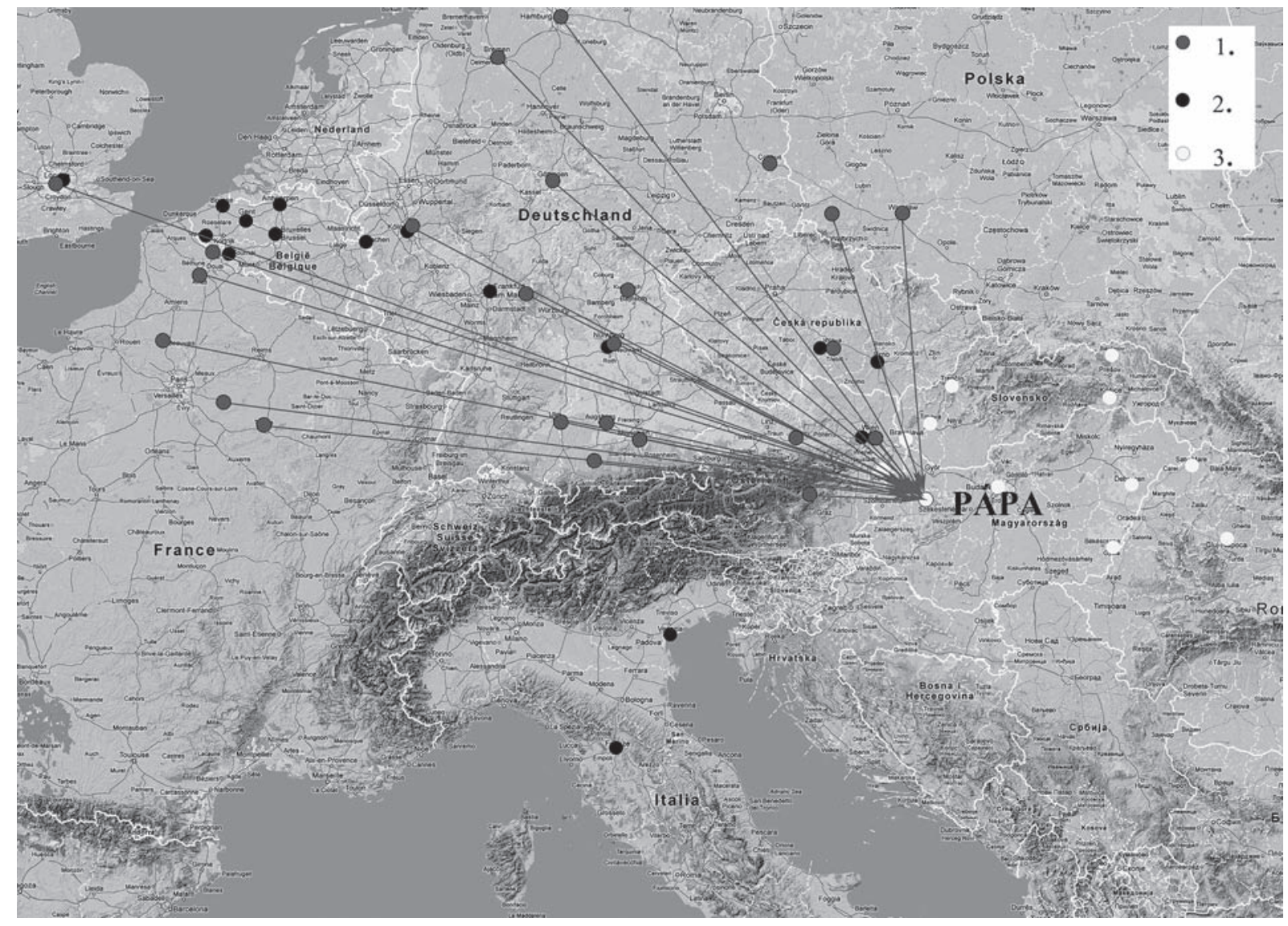

7. kép: A magyarországi textilimport eredete a középkorban és a kora újkorban:

1. az írott forrásokból ismert települések; 2 . a pápai textilplombák származási helyszínei; 3. textilgyártó települések a késö középkori és kora újkori Magyarországon

83 Kühtreiber - Marian 2000. 199 (Abb. 1).

84 Pach 2003. 22-23.

85 Hunka 1999. 299-300. 


\title{
The archaeological traces of the 15th-17th centuries distance cloth-trade in Pápa
}

\author{
MAXIM MORDOVIN
}

The large scale reconstruction works of the historical centre of Pápa in Western Hungary were preceded by rescue excavations. The archaeological research focused on the present day Main square (Fô tér). The territory of the investigated surface reached $1500 \mathrm{~m}^{2}$. The results were from many aspects really unexpected. We could trace the continuous development of the city from its foundation in the 10th century until the late 18th century rearrangement of the main square when it gained is present day appearance.

The earliest rural type settlement on the site lasted until late 13th - early 14th century when it was methodically demolished, its remains were filled up and levelled. This levelling layer was use as a foundation for the pavement of the newly constructed market square. This market basically defined the topography of the city, its development and its life until today. There was a small, most probably deaconry church originated yet from the 12th-13th centuries in the middle of the square. Some remains of its gothic phase have been also unearthed.

The surface of the square was renewed many times, seemingly every 40-60 years or maybe even more often. Each of the surface layers contained enormous amount of archaeological finds including pottery, animal bones, coins, jewellery, different iron objects and rivets, and cloth seals. It was already clarified from the written sources that Pápa played important role in Hungarian textile trade but there were no material traces for this. The discovered 135 pieces of more or less identifiable cloth seals is unique for the whole Hungary. Very interesting is the distribution of their places of origin. Some of them show connections with cities, which do not appear in the contemporary Hungarian written sources.

The cloth seals from Pápa cover the period from the late 15th until the 18th century. Most of them originated from larger textile production centres of Holy Roman Empire: Hamburg, Nuremberg, Cologne, Ulm, and Munich. The newly identified connections located in Kaufbeuren and Kulmbach in Bavaria, and Löwenberg (Lwówek Śląski) in Silesia. The second most important region is Central Europe, namely Austria - Vienna and Tulln, Bohemia and Moravia - Nový Jičín (Neutitschein) and Jihlava (Iglau).

At the present stage of the research this is the largest known collection of cloth seals in the Carpathian Basin (medieval Kingdom of Hungary) from a single site. There are altogether cca. 400 cloth seals from other sites in the Carpathian Basin. The complete evaluation and identification of the finds continues.

\section{Irodalom}

Dietz, A. 1921.: Frankfurter Handelsgeschichte. Zweiter Band. Frankfurt am Main

Egan, G. 1978.: Cloth Seals. London Archaeologist 3. 177-179.

Egan, G. 1992.: Leaden Cloth Seals. Finds Research Group 700-1700. London

Egan, G. 1994.: Lead cloth seals and related items in the British Museum. London

Egan, G. 2010.: Medieval and later trade in textiles between Belgium and England. The picture from some finds of cloth seals. In.: De Groote, K. - Tys, D. - Pieters, M. (Eds.): Exchanging Medieval Material Culture. Studies on archaeology and history presented to Frans Verhaeghe. Brussel, 55-66.

Endrei W. 1989.: Patyolat és posztó. Budapest

Endrei, W. - Egan, G. 1982.: The Sealing of Cloth in Europe, with Special Reference to the English Evidence. Textile History 13. 47-76.

Gawronski, J. 2009.: Amsterdam, een maritieme stad? Amsterdam, 5-29.

Gecsényi L. 1996.: Adatok Pápa szerepéhez a XVI. században a Rába-menti tájegységben. In.: Tanulmányok Pápa város történetéből 2. Szerk.: Hermann István, Pápa, 44-47.

Hittinger, D. 2008.: Tuchplomben. Warenzeichen des späten Mittelalters und der Neuzeit aus dem norddeutschen Küstengebiet. Aachen

Hunka, J. 1999.: Nálezy olovených plômb na zaistovanie prepravovaných tovarov (14.-17. stor.) zo Slovenska. Študijné zvesti Archeologického Ústavu SAV 33. 295-309.

Huszár L. 1961.: Merchants' seals of the 16th and 17th centuries. Folia Archaeologica XIII. 187-194.

Huszár L. 1972.: Ólomplomba a diósgyőri várból. A Miskolci Hermann Ottó Múzeum Közleményei 11. $43-47$.

Janyin 1953.: (Янин, В.) Печати из новгородских раскопок 1951 г. Советская археология 18. 372-385.

Kaiser, R. 1987.: Imitationen von Beschau- und Warenzeichen im späten Mittelalter. Ein Mittel im Kampf um Absatz und Märkte. Vierteljahrschrift für Sozial und Wirtschaftsgeschichte 74. 457-478. 
Kaiser, R. 1988.: Fälschungen von Beschauzeichen als Wirtschaftdelikte im spätmittelalterlichen Tuchgewerbe. In.: Fälschungen im Mittelalter. Internationaler Kongreß der Monumenta Germaniae Historica, München, 16. - 19. September 1986. Teil V. Fingierte Briefe, Frömmigkeit und Fälschung, Realienfälschungen. Hannover, 723-752.

Kaplūnaitè, I. - Jonaitis, R. 2005.: Numizmatiniai ir sfragistiniai radiniai iš Vilniaus Rotušès aikštès. Numizmatika 6. 79-88.

Klimovszkij 1997.: (Климовский С. И.) Находка английской печати XVI в. в Киеве. In: Пятая Всероссийская нумизматическая конференция. Москва, 21-25 апреля 1997 г. Тезисы докладов и сообщений. Москва, 50-52.

Kovács Gy. 2002. (Szerk.): Weitschawar - Bajcsa-vár. Egy stájer erődítmény Magyarországon a 16. század második felében. Zalaegerszeg

Kubinyi A. 1994.: A középkori Pápa. In.: Tanulmányok Pápa város történetéből. A kezdetektől 1970-ig. Szerk.: Kubinyi András, Pápa, 45-76.

Kühtreiber,Th.-Marian,G.2000.:ZweiTuchplomben von derBurgruineSchrattenstein.Ein Beitragzum niederösterreichischen Tuchmachergewerbe im Mittelalter unter besonderer Berücksichtigung der landesfürstlichen Stadt Tulln. Unsere Heimat (Niederösterreich) 71. 198-217.

Mordovin M. 2012.: Előzetes jelentés a Pápa - Fő téren végzett megelőző feltárások második és harmadik üteméről. Régészeti kutatások Magyarországon 2012. (nyomdában)

Mráv Zs. - Szabó Á. 2006.: Rongál-e a kincsvadász?: egy per és egy ítélet tanulságai. Magyar múzeumok 12/2. 25-26.

Munro J. 2005.: Spanish merino wools and the nouvelles draperies: an industrial transformation in the late medieval Low Countries. Economic History Review 58/3. 431-484.

Pach Zs. P. 2003.: Szürkeposztó, szűrposztó, szűr. Fejezetek a magyarországi szövőipar korai történetéből. Budapest

Pálffy G. 1997.: A pápai vár felszabadításának négyszáz éves emlékezete 1597-1997. Pápa

Pálffy G. 1999.: A császárváros védelmében. A győri kapitányság története 1526-1598. Győr

Posthumus, N. W. 1908.: De geschiedenis van de Leidsche lakenindustrie. Deel I. De Middeleeuwen (veertiende tot zestiende eeuw). 's Gravenhage

Posthumus, N. W. 1939.: De geschiedenis van de Leidsche lakenindustrie. Deel II. De Nieuwe Tijd (zestiende tot achtiende eeuw). 's Gravenhage

Rodenburg, N. M. 2011.: 'Seal and Deal.' Cloth Production and Trade between the Netherlands and Scania during the Late Middle Ages and Early Modern Times. Master Thesis, Lund University, Lund

Schütte, S. 1993.: Tuchplomben als städtische Zeichen. Das Falbeispiel Göttingen. Anzeiger des Germanischen Nationalmuseum, 135-141.

S. Laczkovits E. 1996.: Pápa város népélete. In.: Tanulmányok Pápa város történetéből 2. Szerk.: Hermann István, Pápa, 78-81.

Solymosi L. 1996.: Adatok Pápa város középkori történetéhez. In.: Tanulmányok Pápa város történetéből 2. Szerk.: Hermann István. Pápa, 20-31.

Szakály F. 1994.: Pápa a török korban. (1526-1686). In.: Tanulmányok Pápa város történetéből. A kezdetektől 1970-ig. Szerk.: Kubinyi András, Pápa, 77-122.

Tettamanti S. 1994.: A váci vár. Váci könyvek 7. 101-174.

Varga M. 2012.: Késő középkori érmek Visegrád Fő u. 73. lelőhelyről, és előzetes anyagvizsgálati eredményeik. A numizmatika és a társtudományok IX. konferenciája (Kézirat) 